\title{
PERANAN DISIPLIN KERJA DAN KOMPENSASI DALAM MENDETERMINASI KINERJA KARYAWAN DENGAN MOTIVASI KERJA SEBAGAI VARIABEL INTERVENING PADA PT CAHAYA PULAU PURA DI KOTA BATAM
}

\author{
${ }^{1}$ Mauli Siagian \\ ${ }^{1}$ Universitas Putera Batam \\ maulisgn@gmail.com
}

\begin{abstract}
This study aims to examine the extent of work discipline, compensation in mendeterminasi employee performance with work motivation as intervening variables at PT Cahaya Pulau Pura in Batam City, using quantitative research methods with data analysis techniques with path analysis of employees as many as 160 reponden made a sample of a population of 268 employees, whose data were tested using SPSS 21 software tools. The results of the study were; Work discipline has a significant influence on work motivation with the coefficient of direct effect of work discipline on work motivation is 0,513. Compensation has no significant effect on work motivation with coefficient of direct effect of compensation on work motivation is 0,015. Work discipline has a significant effect on employee performance with coefficient of direct effect of work discipline on employee performance is 0,249. Compensation has a significant effect on employee performance with coefficient of direct effect of compensation on employee performance is 0,159. Motivation of work has a significant effect on employee performance with coefficient of direct influence of work motivation on employee performance is 0,559. Coefficient of indirect effect $>$ direct effect $(0.2867>0.249)$. So that work discipline has a significant effect on employee performance through work motivation. Or it could be concluded that the motivation of work as an intervening variable in mediating the relationship of work discipline to the performance of employees. Coefficient of indirect effect $>$ direct influence $(0,1674>0,159)$. So that compensation has a significant effect on employee performance through work motivation. Or it could be concluded that the motivation of work as an intervening variable in mediating the compensation relationship on employee performance.
\end{abstract}

Keywords: work discipline, compensation, work motivation, employee performance

\begin{abstract}
ABSTRAK
Penelitian ini bertujuan untuk menguji sejauh mana disiplin kerja, kompensasi dalam mendeterminasi kinerja karyawan dengan motivasi kerja sebagai variabel intervening pada PT Cahaya Pulau Pura di Kota Batam, dengan menggunakan metode penelitian kuantitatif dengan teknik analisis data dengan analisis jalur terhadap para karyawan sebanyak 160 reponden yang dijadikan sampel dari populasi 268 karyawan, yang pengujian datanya menggunakan alat bantu software SPSS 21. Hasil dari penelitian yaitu; Disiplin kerja memiliki pengaruh yang signifikan terhadap motivasi kerja dengan koefisien pengaruh langsung disiplin kerja terhadap motivasi kerja adalah 0,513 . Kompensasi tidak memiliki pengaruh yang signifikan terhadap motivasi kerja dengan koefisien pengaruh langsung kompensasi terhadap motivasi kerja adalah 0,015. Disiplin kerja memiliki pengaruh yang signifikan terhadap kinerja karyawan dengan koefisien pengaruh langsung disiplin kerja terhadap kinerja karyawan adalah 0,249. Kompensasi memiliki pengaruh yang signifikan terhadap kinerja karyawan dengan koefisien pengaruh langsung kompensasi terhadap kinerja karyawan adalah 0,159 . Motivasi kerja memiliki pengaruh yang signifikan terhadap kinerja karyawan dengan koefisien pengaruh langsung motivasi kerja terhadap kinerja karyawan adalah 0,559 . Nilai koefisien pengaruh tidak langsung $>$ pengaruh langsung $(0,2867>0,249)$. Sehingga disiplin kerja berpengaruh signifikan terhadap kinerja karyawan melalui motivasi kerja. Ataupun bisa juga disimpulkan bahwa motivasi kerja sebagai variabel intervening dalam mengantarai hubungan disiplin kerja terhadap kinerja karyawan. Nilai koefisien pengaruh tidak langsung > pengaruh langsung $(0,1674>0,159)$. Sehingga kompensasi berpengaruh signifikan terhadap kinerja karyawan melalui motivasi kerja. Ataupun bisa juga disimpulkan bahwa motivasi kerja sebagai variabel intervening dalam mengantarai hubungan kompensasi terhadap kinerja karyawan.
\end{abstract}

Kata Kunci: disiplin kerja, kompensasi, motivasi kerja, kinerja karyawan 


\section{PENDAHULUAN}

PT Cahaya Pulau Pura yang berada di Kota Batam menyediakan jasa yang bergerak dalam bidang perhotelan dan entertainment yang didukung oleh 286 tenaga kerja dalam hal ini karyawan yang membantu mengelola dan mengoperasikan setiap aktivitas guna meningkatkan pelayanan yang optimal. Adapun Visi dari PT Caha Pulau Pura mengembangkan merek Hotel yang inovatif untuk menjadi merek terkemuka disetiap pasar yang kami layani. Usaha dalam membuktikan dan mewujudkan visi tersebut pihak PT Cahaya Pulau Pura berupaya untuk meningkatkan kinerja karyawannya dengan cara menerapkan disiplin kerja, pemberian kompensasi juga dukungan motivasi kerja baik dari sesama rekan kerja maupun dari pihak pimpinan. Semakin meningkatnya perkembangan bisnis dalam bidang jasa, yang memasuki kancah persaingan yang global. Pebisnis jasa menawarkan berbagai jasa yang mampu melayani masyarakat yang membutuhkan dalam waktu 24 jam tanpa terkecuali. Semakin meningkatnya penawaran dari pebisnis jasa dikarenakan permintaan masyarakat terhadap kebutuhan jasa meningkat pesat. Bahkan (Paputungan, 2013: 680) menyatakan: dunia bisnis secara dramatis mengalami perubahan secara fundamental, dalam mengikuti arus dari perkembangan. Manajemen perusahaan tidak dapat mengabaikan setiap kebutuhan dan keinginan karyawan, baik secara individu maupun institusi dalam hal ini bidang tugas yang dihadapinya. Masalah rendahnya kinerja karyawan merupakan masalah yang perlu diperhatikan oleh setiap perusahaan, karena kinerja karyawan akan mempengaruhi kualitas dan kuantitas perusahaan dalam menghadapi persaingan seiring dengan perkembangan zaman. Salah satu yang menyebabkan menurunnya kinerja karyawan adalah kurangnya motivasi yang diberikan oleh perusahaan untuk karyawan yang memiliki kinerja yang baik juga program pendisiplinan yang jelas.

Menurut (Soleha, Komara, \& Sudia, 2012: 40) bahwa: perubahan merupakan sebuah kondisi yang terus menerus terjadi dan tidak bisa dihindari, melaju dengan sebuah kecepatan yang sangat cepat, dan dengan perubahan ini otomatis akan menggerus siapa saja yang lambat untuk beradaptasi dengan laju perubahan zaman yang kompleks dan mempengaruhi kemampuan organisasi untuk berkompetisi dan mempertahankan daya saingnya. Peningkatan kualitas kerja pegawai untuk meningkatkan kinerja menjadi mutlak diperlukan oleh seluruh pelaku organisasi. Suatu organisasi yang berorientasi pelayanan, berusaha agar semua sumber daya yang dimiliki dapat didayagunakan secara optimal, sehingga perlu pengelolaan secara efektif.

Masih banyaknya karyawan yang tidak kembali tepat waktu setelah jam istirahat, masih ada karyawan yang mengerjakan hal di luar tugasnya pada jam kerja, terdapat karyawan yang masih mengeluh akan pekerjaannya. Karyawan yang kurang disiplin menyebabkan kinerja yang kurang maksimal, seperti yang dikatakan oleh (Pramadita \& Surya, 2015: 2305) tentang: kedisplinan yang bermasalah saat ini, terlihat dengan menurunnya rasa patuh karyawan terhadap tata-tertib perusahaan, menurunnya tingkat kehadiran karyawan, karyawan sering terlambat masuk kantor dan kurangnya rasa tanggungjawab karyawan terhadap perintah atasan.

$\begin{array}{crrr}\text { Pembayaran } & \text { ataupun pemberian } \\ \text { kompensasi juga } & \text { sangatlah } & \text { penting }\end{array}$ diperhatikan dalam menambah semangat kerja karyawan sehingga akan tercapai nantinya hasil kerja yang diharapkan bahkan akan dapat ditingkatkan dengan adanya pemberian kompensasi sesuai dengan tingkat resiko dari masing-masing pekerjaan. Juga diperkuat (Diputra \& Mujianti, 2016: 2374) menyatakan bahwa: masih saja ada karyawan yang kurang puas dengan kompensasi yang diberikan karena karyawan menganggap bahwa kompensasi yang diterima tidak sesuai dengan beban kerja dan tanggungjawab pekerjaan yang diemban karyawan.

Kompensasi berbasis kinerja mendorong karyawan dapat mengubah kecenderungan semangat untuk memenuhi kepentingan diri sendiri ke semangat untuk memenuhi tujuan organisasi.Secara umum, kinerja karyawan diyakini dipengaruhi oleh karakteristik individu, kompensasi dan motivasi dari karyawan itu sendiri, yang akan berdampak pada kinerja organisasi. Dengan adanya kompensasi yang memadai dan peningkatan motivasi yang dijalankan berhasil, maka seorang karyawan akan termotivasi dalam pelaksanaan pekerjaan yang dibebankan kepadanya dan berupaya mengatasi permasalahan yang terjadi (Malonda, Kojo, \& 
Sepang, 2014: 1461). Pencapaian kinerja yang baik dan sesuai dengan yang diinginkan tidaklah mudah, perlu dilakukan pengawasan dan evaluasi rutin. Dari hasil evaluasi kerja tersebut maka dapat diberikan arahan, dorongan, ataupun masukan kepada karyawan berupa motivasi. Dari hasil penelitian (Nuswantoro \& Kurniawati, 2013: 23) menyatakan bahwa: pemberian motivasi dapat mendorong atau menggerakkan potensi karyawannya agar mau bekerja sama secara produktif berhasil dan mewujudkan tujuan yang telah ditentukan, perusahaan bukan saja mengharapkan mampu, cakap dan terampil, tetapi yang terpenting mereka mau bekerja giat dan keinginan untuk mencapai hasil kerja yang maksimal. Kinerja dipengaruhi oleh motivasi karyawan yang bekerja dalam suatu organisasi, bila motivasi karyawan rendah maka kinerja karyawan akan rendah. Diperkuat oleh (Respatiningsih \& Sudirjo, 2015: 63) mengemukakan bahwa: terdapat pengaruh yang positif dan signifikan antara motivasi terhadap kinerja. Juga oleh(Suparno \& Sudarwati, 2014: 22) menyatakan bahwa: motivasi dan disiplin kerja memiliki pengaruh yang positif dan signifikan terhadap kinerja pegawai baik itu secara parsial maupun secara simultan.

Kinerja karyawan memang masih bersifat individual, dikarenakan setiap karyawan mempunyai tingkat kemampuan yang berbeda dalam mengerjakan tugasnya. Oleh karena itu perlu ditingkatkan dengan melakukan evaluasi terhadap kinerjanya juga memotivasi karyawan dalam penyelesaian pekerjaannya sehingga karyawan tidak merasa terbebani dalam melaksanakan tugas-tugasnya. Penerapan disiplin kerja juga sangatlah perlu untuk meningkatkan kesadaran karyawan akan tanggung jawabnya dimana dapat diselesaikan tepat waktu. Terlepas dari penerapan disiplin sesuai dengan prosedur yang ada sehingga karyawan tetap semangat dalam bekerja harus didukung dengan pemberian kompensasi yang sesuai dengan tingkat kesulitan tanggung jawab masing-masing karyawan, sehingga karyawan akan selalu berupaya melakukan yang terbaik di perusahaan tersebut dengan menunjukkan kinerja yang baik sehingga tercapailah tujuan perusahaan. Dengan adanya penjelasan tersebut sehingga dapat diuraikan rumusan masalahnya, yaitu:

\section{TINJAUAN PUSTAKA}

\section{Pengertian Disiplin Kerja}

Disiplin merupakan modal yang diperlukan dalam mencapai tujuan yang diinginkan. Sehingga keberadaan disiplin kerja amat diperlukan dalam suatu perusahaan, karena dalam suasana disiplin sebuah organisasi atau instansi akan dapat melaksanakan program-program kerjanya mencapai sasaran yang telah ditetapkan (Katiandagho, Mandey, \& Mananeke, 2014: 1594).

Disiplin kerja adalah suatu alat yang digunakan para manajer untuk berkomunikasi dengan karyawan agar mereka bersedia untuk mengubah suatu perilaku serta sebagai suatu upaya untuk meningkatkan kesadaran dan kesediaan seseorang mentaati semua peraturan perusahaan dan norma-norma sosial yang berlaku (Paputungan, 2013: 681).

Disiplin yaitu suatu sikap menghormati, menghargai, patuh dan taat terhadap peraturan-peraturan yang berlaku, baik yang tertulis maupun yang tidak tertulis serta sanggup menjalankannya dan tidak mengelak untuk menerima sanksi-sanksinya apabila ia melanggar tugas dan wewenang yang diberikan kepadanya (Katiandagho et al., 2014: 1594).

Disiplin umumnya diartikan kepatuhan dan ketaatan pada peraturanperaturan atau ketentuan-ketentuan yang berlaku dilingkungan organisasi masingmasing, jika terdapat karyawan yang tidak mematuhi segala peraturan dan ketentuan yang berlaku pada lingkungan kerjanya, berarti tindakan karyawan tersebut dapat dikategorikan sebagai tindakan yang melanggar disiplin (Lumentut \& Dotulong, 2015: 76).

Disiplin kerja dibicarakan dalam kondisi yang sering kali timbul bersifat negatif. Disiplin dikaitkan dengan sangsi atau hukuman. Disiplin di dalam manajemen sumber daya manusia dinyatakan sebagai kualitas usaha yang dilakukan sesuai dengan Standar Operating Procedur (SOP) oleh seseorang unttuk memperoleh barang dan jasa. Pemerintah sebagai sebuah organisasi tentunya memiliki upaya-upaya untuk dapat meningkatkan disiplin pegawai untuk mencapai tujuan organisasi, seperti halnya organisasi lain, Sumber Daya Manusia merupakan penggerak utama organisasi (Suparno \& Sudarwati, 2014: 16). 
Disiplin kerja adalah suatu keadaan tertib dimana seseorang atau sekelompok orang yang tergabung dalam organisasi tersebut berkehendak mematuhi dan menjalankan peraturan-peraturan perusahaan baik yang tertulis maupun tidak tertulis dengan dilandasi kesadaran dan keinsyafan akan tercapainya suatu kondisi antara keinginan, kenyataan dan diharapkan agar para karyawan memiliki sikap disiplin yang tinggi dalam bekerja sehingga produktivitasnya meningkat. Penerapan disiplin bagi pegawai diharapkan dapat meningkatkan kinerja pegawai (Runtunuwu, Lapian, \& Dotulong, 2015: 82). Sedangkan menurut (Supriyadi, Priadana, \& Setia, 2017: 26) disiplin kerja merupakan pelaksanaan manajemen untuk memperteguh pedoman-pedoman organisasi. Menurut (Darmawan, 2013: 55) terdapat tujuh indikator disiplin kerja, yaitu; penyampaian informasi, manajer paham aturan kerja, tegas pada pelanggaran, konsisten, sesuai prosedur, langsung, penyampaian benar.

\section{Pengertian Kompensasi}

Kompensasi merupakan faktor yang penting bagi perusahaan karena kompensasi dapat menarik, memelihara, dan mempertahankan tenaga kerja serta mendorong tenaga kerja untuk lebih produktif. Secara umum tujuan manajemen kompensasi adalah untuk membantu perusahaan mencapai tujuan keberhasilan strategi perusahaan dan menjamin terciptanya keadilan internal dan eksternal. Dengan adanya kompensasi yang adil dapat memacu kinerja karyawan menjadi optimal (Diputra \& Mujianti, 2016: 2374).

Kompensasi adalah imbalan jasa/balas jasa yang diberikan oleh perusahaan kepada tenaga kerja, karena tenaga kerja tersebut telah memberikan sumbangan dan pikiran demi kemajuan dan kontinuitas perusahaan dalam rangka mencapai tujuan yang telah ditetapkan, baik dalam jangka pendek maupun dalam jangka panjang (Malonda et al., 2014: 1462).

Kompensasi merupakan sesuatu yang diterima karyawan sebagai balas jasa dari kontribusi jasa mereka pada perusahaan. Kompensasi meliputi bentuk pembayaran tunai langsung, pembayaran tidak langsung dalam bentuk manfaat karyawan, dan insentif untuk memotivasi karyawan agar bekerja lebih keras untuk mencapai produktivitas yang tinggi. Tujuan manajemen kompensasi adalah untuk membantu pencapaian tujuan keberhasilan strategis perusahaan dan menjamin terjadinya keadilan internal dan eksternal (Supriyadi et al., 2017: 26).

Kompensasi merupakanksalah satu bentukkpenghargaan suatu organisasi terhadapksumber daya manusiakyang terlibat di dalamnya, kompensasi yang sesuai dan tepat dapat memberikan pemenuhan kebutuhan dasar karyawan (Nugraha \& Surya, 2016: 67). Kompensasi adalah semua pendapatan yang berbentuk uang, barang langsung atau tidak langsung yang diterima karyawan sebagai imbalan atas jasa yang diberikan kepada perusahaan (Liando, Tewal, \& Walangitan, 2016: 435). Sedangkan menurut (Pioh \& Tawas, 2016: 840) kompensasi merupakan penghargaan/ganjaran pada para pekerja yang telah memberikan kontribusi dalam mewujudkan tujuannya, melalui kegiatan yang disebut bekerja.

Kompensasi dasar diperlukan untuk mempertahankan karyawan dengan standar hidup yang layak, akan tetapi kompensasi juga menyediakan suatu pengukuran berwujud mengenai nilai individu bagi perusahaan. Pemberian kompensasi merupakan fungsi strategik sumber daya manusia yang mempunyai imbas singnifikan atas fungsifungsi sumber daya manusia lainnya (Nurcahyani \& Adnyani, 2016: 504). Kompensasi adalah imbalan jasa/balas jasa yang diberikan oleh perusahaan kepada tenaga kerja, karena tenaga kerja tersebut telah memberikan sumbangan dan pikiran demi kemajuan dan kontinuitas perusahaan dalam rangka mencapai tujuan yang telah ditetapkan, baik dalam jangka pendek maupun dalam jangka panjang (Malonda et al., 2014: 1464).

Kompensasi adalah segala bentuk imbalan yang diberikan oleh perusahaan kepada pegawainya atas pengorbanan pegawai yang bersangkutan. Pengorbanan pegawai tersebut dapat berupa kerja, jasa kinerja, biaya, maupun jerih payah yang dikeluarkan untuk mencapai tujuan tertentu yang telah ditetapkan oleh perusahaan (Maddinsyah \& Wahyudi, 2017: 33). Menurut (Rizal, Syafiie Idrus, \& Mintarti, 2014: 65) terdapat tiga indikator kompensasi yang berperan penting untuk meningkatkan motivasi dan kinerja karyawan, yaitu; gaji, inentif, dan tunjangan.

\section{Pengertian Motivasi Kerja}

Menurut (Poniasih \& Dewi, 2015: 1562) motivasi adalah keinginan untuk melakukan sebagai kesediaan untuk mengeluarkan tingkat upaya yang tinggi untuk 
tujuan-tujuan organisasi. Sedangkan menurut (Permansari, 2013: 2) motivasi merupakan sebuah dorongan yang tumbuh dalam diri seseorang. Baik yang berasal dari dalam maupun dari luar dirinya untuk melakukan suatu pekerjaan dengan semangat tinggi menggunakan semua kemampuan dan ketrampilan yang dimilikinya guna mencapai tujuan organisasi.

Menurut (Sari, Muis, \& Hamid, 2012: 88) Motivasi itu sendiri merupakan faktor yang paling menentukan bagi seorang pegawai dalam bekerja. Meskipun kemampuan dari pegawai maksimal disertai dengan kelengkapan fasilitas yang memadai, namun jika tidak ada motivasi untuk melakukan pekerjaan tersebut maka pekerjaan itu tidak akan berjalan sebagaimana yang diharapkan.

Motivasi diartikan sebagai keadaan dalam pribadi seseorang yang mendorong individu untuk melakukan kegiatan-kegiatan tertentu guna mencapai tujuan organisasi (Respatiningsih \& Sudirjo, 2015: 58).

Motivasi adalah proses yang menjelaskan intensitas, arah, dan ketekunan seorang individu untuk mencapai tujuannya. Juga dorongan atau kehendak yang menyebabkan seseorang berbuat sesuatu. Perilaku seseorang itu hakikatnya ditentukan oleh keinginannya untuk mencapai beberap tujuan. Keinginan itu istilah lainnya ialah motivasi. Dengan demikian motivasi merupakan pendorong agar seseorang itu melakukan suatu kegiatan untuk mencapai tujuan (Potu, 2013: 1210).

Motivasi merupakan suatu motif adalah kondisi terdalam yang dapat memberikan energi untuk menggerakkan dan menggarahkan perilaku terhadap tujuan (Motive is an inner state that is an energizer to move hence motivation and that directs behavior toward goal) (Simoes, Riana, \& Subudi, 2017: 3466).

Motivasi merupakan akibat dari interaksi seseorang dengan situasi tertentu yang dihadapinya. Karena itulah terdapat perbedaan dalam kekuatan motivasi yang ditunjukkan oleh seseorang dalam menghadapi situasi tertentu dibandingkan dengan orangorang lain yang menghadapi situasi tertentu dibandingkan dengan orang-orang lain yang menghadapi situasi yang sama (Susanti \& Widayat, 2016: 154). Menurut (Rizal et al., 2014: 75) terdapat tiga indikator motivasi kerja yang berperan penting untuk meningkatkan kinerja karyawan, yaitu; kebutuhan pencapaian, kebutuhan berafiliasi, kebutuhan tenaga.

\section{Pengertian Kinerja Karyawan}

Kinerja karyawan adalah catatan outcome yang dihasilkan dari suatu pekerjaan atau kegiatan tertentu selama suatu periode waktu tertentu juga merupakan tingkat keberhasilan dalam melaksanakan tugas dan kemampuan untuk mencapai tujuan yang telah ditetapkan (Priadana \& Ruswandi, 2013: 57). Sedangkan menurut (Runtunuwu et al., 2015: 83) kinerja merupakan hasil kerja secara kualitas maupun kuantitas yang dicapai oleh seseorang dalam melaksanakan tugasnya sesuai dengan tanggung jawab yang diberikan kepadanya.

Kinerja atau performa sumber daya manusia (SDM) sebagai tenaga kerja, pada dasarnya merupakan kualitas pengetahuan, keterampilan dan sikap mental seorang pekerja. Seseorang harus mempunyai hasil kerja yang dapat dicapai di dalam organisasi sesuai dengan tugas dan tanggung jawab masing-masing dalam rangka mencapai tujuan organisasi, tidak melanggar hukum serta sesuai dengan moral dan etika. Kinerja hanya berlaku dalam sebuah organisasi, dimana ada aturan, skala, alat ukuran (tools), dan ada orang yang melaksanakannya (actors) serta ada sekumpulan orang serta ada tujuan organisasi tersebut (Marpaung, 2014: 36).

Kinerja seseorang merupakan kombinasi dari kemampuan, usaha dan kesempatan yang dapat dinilai dari hasil kerjanya. Performance diterjemahkan menjadi kinerja, juga berarti prestasi kerja, pelaksana kerja, pencapaian kerja atau hasil kerja/unjuk kerja/penampilan kerja (Atolllah, 2014: 4).

Kinerja (prestasi kerja) karyawan adalah prestasi aktual karyawan dibandingkan dengan prestasi yang diharapkan dari karyawan. Prestasi kerja yang diharapkan adalah prestasi standar yang disusun sebagai acuan sehingga dapat melihat kinerja karyawan sesuai dengan posisinya dibandingkan standar yang dibuat. Selain itu dapat juga dilihat kinerja dari karyawan tersebut terhadap karyawan lainnya (Rudie Yobie, Bernhard, \& Lengkong, 2015: 719).

Kinerja pada umumnya diartikan sebagai kesuksesan seseorang dalam melaksanakan suatu pekerjaan. Kinerja karyawan merupakan hasil kerja yang dicapai seseorang dalam melaksanakan tugas-tugas 
yang dibebankan kepadanya untuk mencapai target kerja. Kinerja karyawan merupakan salah satu faktor penentu keberhasilan perusahaan atau organisasi dalam mencapainya (Susanti \& Widayat, 2016: 154).

Sedangkan menurut (Wahyudi \& Sudibya, 2016: 871) kinerja adalah hasil kerja selama periode tertentu dibandingkan dengan berbagai kemungkinan, misal standar,target/sasaran atau kriteria yang telah disepakati bersama. Menurut (Priadana \& Ruswandi, 2013: 58) terdapat tujuh indikator dari kinerja karyawan, yaitu; quantity of work, quality of work, job knowledge, creativiness, cooperation, depandability, initiative, personal qualitie.

\section{Penelitian Terdahulu}

1. Menurut (Nair \& Ganesh, 2016: 1355) temuan penelitian membahas; Effects Of Motivation, Stress And Compensation Benefits On Employee Performance In It Professionals, yaitu: Kompensasi berhubungan positif dengan kinerja, demikian juga motivasi. Dari temuan penelitian ini, disimpulkan bahwa dukungan sosial di tempat kerja yang diberikan oleh manajemen, atasan dan rekan kerja diperlukan untuk menjaga agar karyawan tetap termotivasi sehingga mengembangkan lingkungan kerja yang sehat. Selanjutnya, membangun sistem penghargaan berbasis kinerja dapat meningkatkan tingkat motivasi karyawan menjadi sangat produktif.

2. Menurut (Negash, Zewude, \& Megersa, 2014: 10) temuan penelitian membahas; The Effect Of Compensation On Employees Motivation: In Jimma University Academic Staff, yaitu: Ada hubungan yang signifikan dan positif antara kompensasi dan motivasi kerja. Penelitian ini menunjukkan bahwa responden termotivasi dan puas dalam sistem pembayaran disimpulkan bahwa pembayaran untuk karyawan seperti over loud, extension dan summers tidak adil dan memotivasi karyawan. Apresiasi di tempat kerja dengan pemberian kompensasi yang seimbang merupakan salah satu faktor penyebab meningkatnya motivasi kerja.
3. Menurut (Rizal et al., 2014: 76) temuan penelitian membahas; Effect of Compensation on Motivation, Organizational Commitment and Employee Performance (Studies at Local Revenue Management in Kendari City), yaitu:

a. Kompensasi berkontribusi dalam meningkatkan kinerja karyawan yang diwujudkan dengan kuantitas, kualitas, dan waktu. Artinya kompensasi yang tinggi yang tidak sesuai dengan kondisi gaji pegawai, insentif dan tunjangan tidak selalu mampu meningkatkan kinerja pegawai.

b. Motivasi memainkan peran penting untuk meningkatkan kinerja karyawan. Artinya motivasi tinggi akan memberikan arti yang sangat signifikan untuk meningkatkan kinerja karyawan.

c. Hubungan langsung antara kompensasi dan kinerja karyawan positif namun tidak signifikan. Hal ini berbeda dengan pengaruh hubungan tidak langsung yang dimediasi oleh motivasi dan kinerja karyawan akan meningkat bila dimediasi oleh motivasi

4. Menurut (Anyim, Chidi, \& Badejo, 2012: 38) temuan penelitian membahas; Motivation and Employees' Performance in the Public and Private Sectors in Nigeria, yaitu: Untuk mendapatkan kinerja yang lebih baik, faktor motivasi harus diberi prioritas tinggi dan dipekerjakan dengan baik sebagai unsur penting untuk kemajuan dan kelangsungan hidup organisasi. Tingkat motivasi yang tinggi sangat diharapkan dari sudut pandang para pemimpin dan manajer di dalam organisasi dan karyawan individual. Penting juga agar organisasi menghabiskan waktu dan usaha untuk meningkatkan motivasi dan kinerja. Selanjutnya, ketika tingkat motivasi tinggi dalam organisasi, maka karyawan melakukan yang terbaik, menikmati pekerjaan 
mereka dan berkinerja baik di tempat kerja.

5. Menurut (Ibrahim \& Brobbey, 2015: 1234) temuan penelitian membahas; Impact of Motivation on Employee Performance the Case of Some Selected Micro Finance Companies in Ghana, yaitu: motivasi merupakan faktor penting dalam menentukan kepuasan dan kinerja karyawan. Apa yang memotivasi karyawan berada di luar penghargaan uang dan mencakup penghargaan intrinsik dan ekstrinsik. Selain itu, motivasi bersifat individual karena kebutuhan individu berbedabeda. Oleh karena itu, motivasi harus ditargetkan pada kebutuhan individu dan kelompok yang memuaskan daripada menggeneralisasi paket motivasi di seluruh organisasi untuk mencapai kinerja yang optimal.

\section{Kerangka Pemikiran}

Kerangka pemikiran yang baik akan mengidentifikasi variabel penting yang relevan dengan permasalahan penelitian dan secara logis/masuk akal dapat menjelaskan keterkaitan/hubungan variable bebas dengan terikat, intervening dan moderating variable (Rumengan, 2013: 27). Dari uraian diatas, maka penulis dapat membuat suatu kerangka pemikiran sebagai berikut:

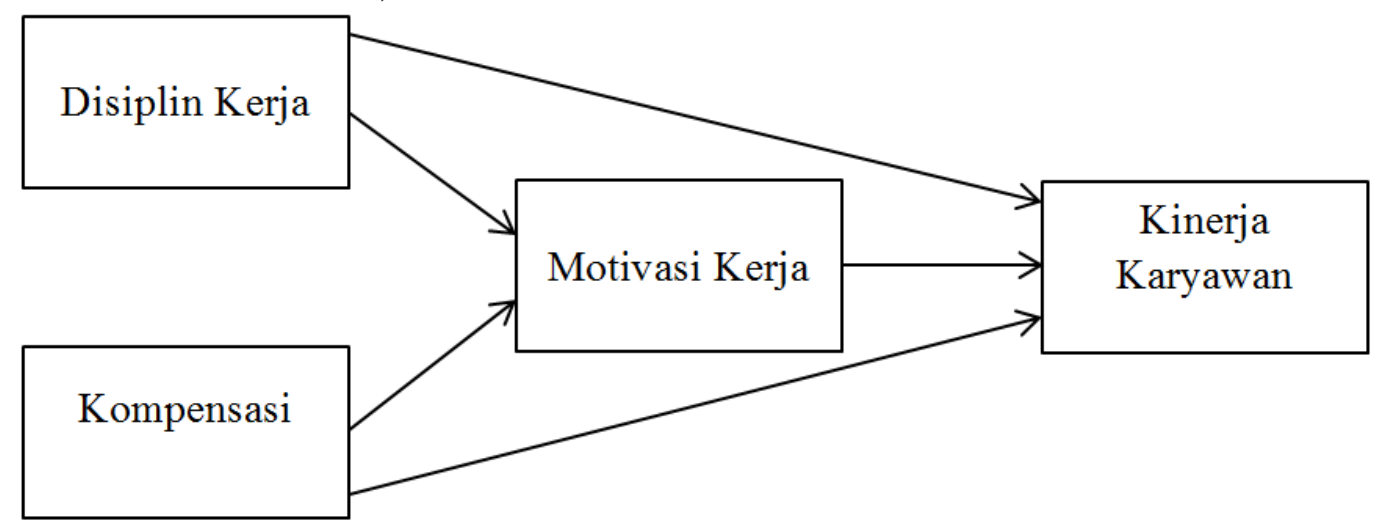

Gambar 2.1 Kerangka Pemikiran

\section{Hipotesis Penelitian}

$\mathrm{H}_{1}$ : Disiplin kerja mendeterminasi motivasi kerja pada PT Cahaya Pulau Pura di Kota Batam.

$\mathrm{H}_{2}$ : Kompensasi mendeterminasi motivasi kerja pada PT Cahaya Pulau Pura di Kota Batam.

$\mathrm{H}_{3}$ : Motivasi kerja mendeterminasi kinerja karyawan pada PT Cahaya Pulau Pura di Kota Batam.

$\mathrm{H}_{4}$ : Disiplin kerja mendeterminasi kinerja karyawan pada PT Cahaya Pulau Pura di Kota Batam.

ilmiah berfokus pada metode yang kokoh untuk mengidentifikasi permasalahan, mengumpulkan data, menganalisis data dan menarik kesimpulan dengan valid dan bersifat objektif. Paradigma kuantitatif menekankan pada pengujian teori melalui pengukuram variable dengan angka dan melakukan analisis data dengan prosedur statistik. Penelitian yang menggunakan pendekatan deduktif yang bertujuan untuk menguji hipotesis (Rumengan,
$\mathrm{H}_{5}$ : Kompensasi mendeterminasi kinerja karyawan pada PT Cahaya Pulau Pura di Kota Batam.

$\mathrm{H}_{6}$ : Disiplin kerja mendeterminasi kinerja karyawan melalui motivasi kerja pada PT Cahaya Pulau Pura di Kota Batam.

$\mathrm{H}_{7}$ : Kompensasi mendeterminasi kinerja karyawan melalui motivasi kerja pada METODE PT Cahaya Pulau Pura di Kota Batam.

Penelitian ini menggunakan metode ilmiah. Menurut (Rumengan, 2013: 6) bahwa metode ilmiah merupakan epistemology ilmu yang mengkaji sumber-sumber untuk memperoleh kajian yang benar. Penelitian 2013: 10) sedangkan statistik hanya meliputi pengumpulan fakta-fakta berupa data yang dikumpulkan (Rumengan, 2013: 5). Populasi dalam penelitian ini keseluruhan karyawan PT Cahaya Pulau Pura Batam Provinsi Kepulauan Riau yang berada di Komplek Komplek Nagoya Paradise Centre, Blok AACC No. 1117 Kota Batam sebanyak 268 orang karyawan, sehingga dari populasi ini perlu ditentukan jumlah sampel menggunakan rumus Slovin 
menjadi 160 reponden. Teknik sampling yang digunakan adalah random sampling. Teknik pengumpulan data dalam penelitian ini yaitu menggunakan probability sampling dengan alat bantu kuesioner, dan dalam bentuk kuesioner dengan pertanyaan tertutup yakni jawaban unit analisis sudah dibatasi sehingga memudahkan dalam perhitungan-perhitungan data yang akan diolah nantinya.

\section{HASIL ANALISIS DAN PEMBAHASAN Karakteristik Responden}

Berdasarkan jenis kelamin tidak begitu tinggi, dimana responden memang lebih banyak laki-laki tapi selisihnya sedikit yaitu laki-laki 50,6\%, dan perempuan 49,4\% , berarti hanya selisih $1,2 \%$ saja. Berdasarkan umur 20-25tahun sebanyak $23,8 \%$, umur 2630 tahun sebanyak 51,3\%, umur 30-35 tahun sebanyak 21,3\%, umur >35 tahun sebanyak $3,8 \%$. Sehingga dapat disimpulkan bahwa berdasarkan umur didominasi 26-30 tahun sebanyak $51,3 \%$. Sebagian besar responden berpendidikan SMK/SMA sebesar 60,6\% dan disusul dengan yang berpendidikan S1 sebesar $27,5 \%$, juga yang berpendidikan D3 sebesar $7,5 \%$, selanjutnya yang berpendidikan $\mathrm{S} 2$ sebesar 4,4\%. Berdasarkan status karyawan didominasi dengan status kontrak yaitu sebanyak $86,9 \%$, sedangkan status permanen hanya $13,1 \%$ saja.

Tabel 1 Hasil Uji Validitas Disiplin Kerja

\begin{tabular}{|c|c|c|c|c|}
\hline $\begin{array}{c}\text { No. } \\
\text { Item }\end{array}$ & $\begin{array}{c}\text { Koefisien } \\
\text { Korelasi (r) }\end{array}$ & $\begin{array}{c}\text { Nilai Batas/ } \\
\text { Nilai Kritis }\end{array}$ & $\begin{array}{c}\text { Tingkat Hubungan } \\
\text { Koefisien }\end{array}$ & Keterangan \\
\hline X1-1 & 0,597 & 0,300 & Cukup Kuat & Valid \\
\hline X1-2 & 0,563 & 0,300 & Cukup Kuat & Valid \\
\hline X1-3 & 0,582 & 0,300 & Cukup Kuat & Valid \\
\hline X1-4 & 0,455 & 0,300 & Cukup Kuat & Valid \\
\hline X1-5 & 0,558 & 0,300 & Cukup Kuat & Valid \\
\hline
\end{tabular}

Sumber: Hasil olah data kuesioner, 2018

Tabel 2 Hasil Uji Validitas Kompensasi

\begin{tabular}{|c|c|c|c|c|}
\hline $\begin{array}{c}\text { No. } \\
\text { Item }\end{array}$ & $\begin{array}{c}\text { Koefisien } \\
\text { Korelasi (r) }\end{array}$ & $\begin{array}{c}\text { Nilai Batas/ } \\
\text { Nilai Kritis }\end{array}$ & $\begin{array}{c}\text { Tingkat Hubungan } \\
\text { Koefisien }\end{array}$ & Keterangan \\
\hline X2-1 & 0,669 & 0,300 & Kuat & Valid \\
\hline X2-2 & 0,603 & 0,300 & Kuat & Valid \\
\hline X2-3 & 0,507 & 0,300 & Cukup Kuat & Valid \\
\hline X2-4 & 0,594 & 0,300 & Cukup Kuat & Valid \\
\hline X2-5 & 0,433 & 0,300 & Cukup Kuat & Valid \\
\hline
\end{tabular}

Sumber: Hasil olah data kuesioner, 2018

Tabel 3 Hasil Uji Validitas Motivasi kerja

\begin{tabular}{|c|c|c|c|c|}
\hline $\begin{array}{c}\text { No. } \\
\text { Item }\end{array}$ & $\begin{array}{c}\text { Koefisien } \\
\text { Korelasi (r) }\end{array}$ & $\begin{array}{c}\text { Nilai Batas/ } \\
\text { Nilai Kritis }\end{array}$ & $\begin{array}{c}\text { Tingkat Hubungan } \\
\text { Koefisien }\end{array}$ & Keterangan \\
\hline Y-1 & 0,730 & 0,300 & Kuat & Valid \\
\hline Y-2 & 0,697 & 0,300 & Kuat & Valid \\
\hline Y-3 & 0,611 & 0,300 & Kuat & Valid \\
\hline Y-4 & 0,675 & 0,300 & Kuat & Valid \\
\hline Y-5 & 0,711 & 0,300 & Kuat & Valid \\
\hline
\end{tabular}

Sumber: Hasil olah data kuesioner, 2018

Tabel 4 Hasil Uji Validitas Kinerja Karyawan

\begin{tabular}{|c|c|c|c|c|}
\hline $\begin{array}{c}\text { No. } \\
\text { Item }\end{array}$ & $\begin{array}{c}\text { Koefisien } \\
\text { Korelasi (r) }\end{array}$ & $\begin{array}{c}\text { Nilai Batas/ } \\
\text { Nilai Kritis }\end{array}$ & $\begin{array}{c}\text { Tingkat Hubungan } \\
\text { Koefisien }\end{array}$ & Keterangan \\
\hline Z-1 & 0,482 & 0,300 & Cukup Kuat & Valid \\
\hline Z-2 & 0,611 & 0,300 & Kuat & Valid \\
\hline Z-3 & 0,760 & 0,300 & Kuat & Valid \\
\hline Z-4 & 0,604 & 0,300 & Kuat & Valid \\
\hline Z-5 & 0,561 & 0,300 & Cukup Kuat & Valid \\
\hline
\end{tabular}

Sumber: Hasil olah data kuesioner, 2018 


\section{Hasil Uji Reliabilitas}

Tabel 5 Hasil Uji Reliabilitas

\begin{tabular}{|l|l|l|l|l|}
\hline Nama Variabel & Cronbach's Alpha & Reliabel $>0,600$ & N of Items & Kesimpulan \\
\hline Disiplin kerja & 0,704 & $>0,600$ & 5 & Reliabel \\
\hline Kompensasi & 0,708 & $>0,600$ & 5 & Reliabel \\
\hline Motivasi kerja & 0,772 & $>0,600$ & 5 & Reliabel \\
\hline Kinerja karyawan & 0,735 & $>0,600$ & 5 & Reliabel \\
\hline
\end{tabular}

Sumber: Olah data dengan SPSS 21, 2018

\section{Hasil Uji Normalitas}

Tabel 6 One-Sample Kolmogorov-Smirnov Test

\begin{tabular}{|ll|r|}
\hline & & $\begin{array}{c}\text { Unstandardized } \\
\text { Residual }\end{array}$ \\
\hline $\mathrm{N}$ & Mean & 160 \\
Normal Parameters & a,b & .0000000 \\
& Std. Deviation & 1.26607427 \\
Most Extreme & Absolute & .084 \\
Differences & Positive & .084 \\
Kolmogorov-Smirnov Z & Negative & -.043 \\
Asymp. Sig. (2-tailed) & & 1.056 \\
\hline
\end{tabular}

Sumber: Olah data dengan SPSS 21, 2018

Pada gambar tersebut diatas, diperoleh bahwa hasil untuk pengolahan data yang ada dalam penelitian dengan penggunaan KolmogorovSmirnov dengan taraf signifikansi $(\alpha)>0,05$ yaitu 0,214 >0,05. Dengan demikian hal ini telah memenuhi kriteria dari asumsi normalitas data. Sehingga dapat diambil kesimpulan bahwa data dalam penelitian ini berasal dari data yang distribusi normal.

\section{Pengujian Model Analisis Jalur}

Tabel 7 Koefisien X1, X2 Terhadap Y

Coefficients $^{\mathrm{a}}$

\begin{tabular}{|l|r|r|r|r|r|}
\hline \multirow{2}{*}{ Model } & \multicolumn{2}{|c|}{ Unstandardized Coefficients } & Standardized Coefficients & \multirow{2}{*}{ S } & \multirow{2}{*}{ Sig. } \\
\cline { 2 - 4 } & \multicolumn{1}{|c|}{ B } & Std. Error & Beta & & \\
\hline (Constant) & 6.997 & 1.808 & & 3.870 & .000 \\
1 DisiplinKerja & .637 & .100 & .513 & 6.383 & .000 \\
Kompensasi & .018 & .096 & .015 & .192 & .848 \\
\hline
\end{tabular}

Sumber: Olah data dengan SPSS 21, 2018

Tabel 8 Koefisien X1, X2, Y Terhadap Z

Coefficients $^{\mathrm{a}}$

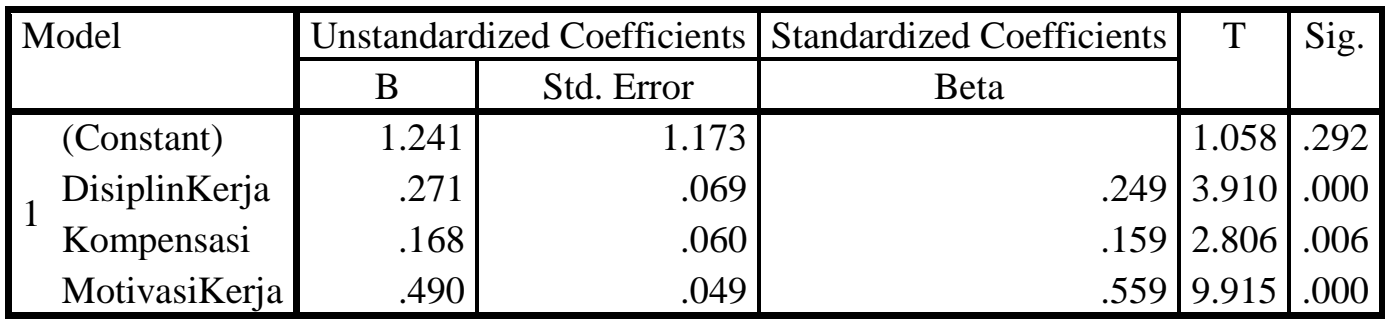

Sumber: Olah data dengan SPSS 21, 2018 


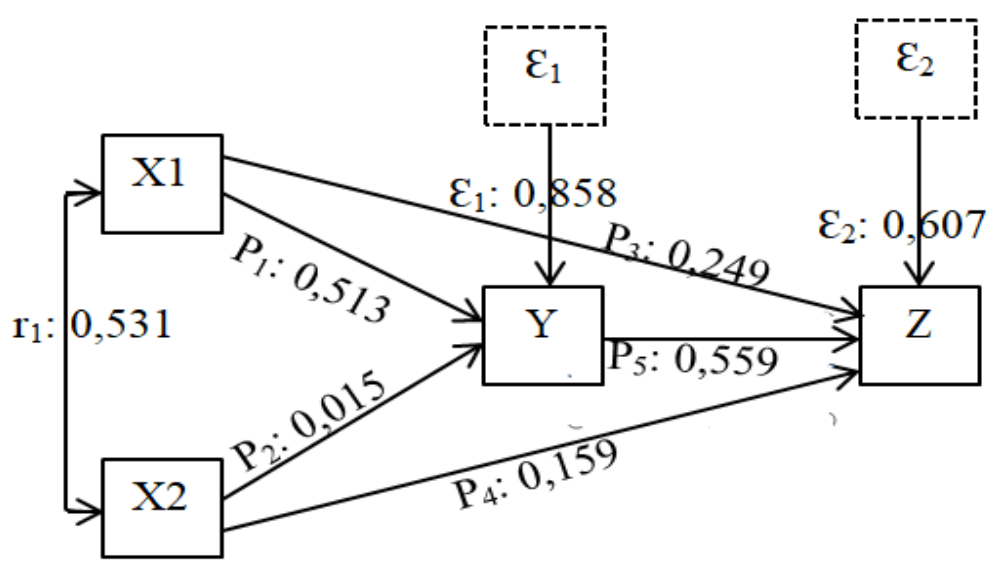

Gambar 9 Model Koefisien Persamaan Jalur II 2685.

Pengujian hipotesis analisis jalur dalam penelitian ini adalah berguna untuk melihat variabel-variabel yang signifikan atau tidak, suatu pengaruh langsung dan tidak langsung dalam penelitian ini. Hipotesisnya adalah: Ho: $\mathrm{P}=0$ adalah tidak ada pengaruh secara signifikan dan Ha: $\mathrm{P} \neq 0$ adalah ada pengaruh secara signifikan (tolak Ho jika nilai Sig. $<\alpha$ 0,05 atau terima Ho jika nilai Sig. $>\alpha 0,05$ ).

\section{SIMPULAN}

Sehingga bisa ditarik kesimpulan dalam penelitian ini bahwa nilai koefisien pengaruh tidak langsung $>$ pengaruh langsung $\left(\mathrm{P}_{2} \times \mathrm{P}_{5}>\mathrm{P}_{4}\right)$ atau $(0,015 \times 0,559>0,159)$ atau $0,1674>0,159$. Sehingga kompensasi (X2) berpengaruh signifikan terhadap kinerja karyawan (Z) melalui motivasi kerja (Y). Ataupun bisa juga disimpulkan bahwa motivasi kerja (Y) sebagai variabel intervening dalam mengantarai hubungan kompensasi (X2) terhadap kinerja karyawan (Z).

\section{DAFTAR PUSTAKA}

Anyim, C. F., Chidi, O. C., \& Badejo, A. E. (2012). Motivation and Employees' Performance in the Public and Private Sectors in Nigeria. International Journal of Business Administration, ISSN: 19234007 \& E-ISSN: 1923-4015, 3(1), 31-40. https://doi.org/10.5430/ijba.v3n1p31

Atolllah, M. (2014). Analisis Pengaruh Gaya Kepemimpinan Dan Motivasi Terhadap Kinerja Pegawai Kelurahan Di Kecamatan Lumajang Kabupaten Lumajang. Jurnal WIGA, ISSN: 20880944, 4(1), 1-18.

Azis, A., \& Djamudin. (2013). Pengaruh Kepemimpinan Terhadap Kinerja Karyawan Housekeeping Departemen (Studi Kasus Pada Hotel Grand Cempaka Jakarta). Jurnal Manajemen, ISSN: 1412-
Chirasha, V. (2013). Management of Discipline for good Performance: A theoretical perspective. Online Journal of Social Sciences Research, ISSN: $2277-$ 0844, 2(7), 214-219.

Darmawan, D. (2013). Prinsip-prinsip Perilaku Organisasi (Kesatu). Surabaya: Pena Semesta.

Diputra, Y. I. N. Y., \& Mujianti, N. W. (2016). Pengaruh Kompensasi, Kepemimpinan dan Lingkungan Kerja Terhadap Kinerja Karyawan Pada Hotel Griya Santrian. EJurnal Manajemen Unud, ISSN: 23028912, 5(4), 2369-2395.

Ibrahim, M., \& Brobbey, V. A. (2015). Impact of Motivation on Employee Performance the Case of Some Selected Micro Finance Companies in Ghana. International Journal of Econor:Commerce and Management, I: 32 2348-0386, III(11), 1218-1236. Retrieved from http://ijecm.co.uk/

Jayaweera, T. (2015). Impact of Work Environmental Factors on Job Performance, Mediating Role of Work Motivation: A Study of Hotel Sector in England. International Journal of Business and Management, ISSN: 18333850, E-ISSN: 1833-8119, 10(3), 271278.

https://doi.org/10.5539/ijbm.v10n3p271

Katiandagho, C., Mandey, S. L., \& Mananeke, L. (2014). Pengaruh Disiplin Kerja Kepemimpinan Dan Motivasi Terhadap Kinerja Pegawai Pada PT. PLN (PERSERO) Wilayah Suluttenggo Area Manado. Jurnal EMBA, ISSN: 2.3031174, 2(3), 1592-1602. 31

Liando, L., Tewal, B., \& Walangitan, M. ע. (2016). Pengaruh Kompensasi, 
Komunikasi, Dan Disiplin Kerja Terhadap Kinerja Karyawan Di PT. Telkom TBK Manado. Jurnal EMBA, ISSN: 2303-1174, 4(5), 433-446.

Lumentut, M. D. ., \& Dotulong, L. O. . (2015). Pengaruh Motivasi, Disiplin, dan Lingkungan Kerja Terhadap Kepuasan Kerja Karyawan Pada PT. Bank SULUT Cabang Airmadidi. Jurnal EMBA, ISSN: 2303-1174, 3(1), 74-85.

Maddinsyah, A., \& Wahyudi. (2017). Pengaruh Kompensasi, Disiplin Kerja, Dan Lingkungan Kerja Terhadap Kinerja Dosen Universitas Swasta Di Wilayah Kopertis IV Provinsi Banten. E-Jurnal KREATIF, ISSN: 2406-8616, 5(1), 3044.

Malonda, W. C., Kojo, C., \& Sepang, J. L. (2014). Karakteristik Individu, Kompensasi Dan Motivasi Karyawan Pengaruhnya Terhadap Kinerja Karyawan PT. Bank Sulut (PERSERO) TBK. Jurnal EMBA, ISSN : 2303-1174, 2(2), 1460-1470. https://doi.org/10.1101/106534

Marpaung, M. (2014). Pengaruh Kepemimpinan Dan Team Work Terhadap Kinerja Karyawan Di Koperasi Sekjen Kemdikbud Senayan Jakarta. Jurnal Ilmiah WIDYA, ISSN: 2337-6686, 2(April).

Nair, P., \& Ganesh, S. (2016). Effects Of Motivation, Stress And Compensation Benefits On Employee Performance In It Professionals. International Journal of Advances Research, ISSN: 2320-5407, 4(1), 1349-1357.

Negash, R., Zewude, S., \& Megersa, R. (2014). The Effect Of Compensation On Employees Motivation: In Jimma University Academic Staff. Basic Research Journals of Business Management and Accounts (BRJ), ISSN: 2315-6899, 3(2), 17-27.

Nugraha, M. B. I., \& Surya, I. B. K. (2016). Pengaruh Kompensasi, Lingkungan Kerja Dan Promosi Jabatan Terhadap Kepuasan Kerja. E-Jurnal Manajemen Unud, ISSN: 2302-8912, 5(1), 59-87.

Nurcahyani, N. M., \& Adnyani, I. G. . D. (2016). Pengaruh Kompensasi Dan Motivasi Terhadap Kinerja Karyawan Dengan Kepuasan Kerja Sebagai Variabel Intervening. E-Jurnal Manajemen Unud, ISSN: 2302-8912,
5(1), 500-532.

Nuswantoro, B., \& Kurniawati, D. (2013). Pengaruh Kepemimpinan , Budaya Organisasi dan Motivasi terhadap Kinerja Karyawan PT Sinarmas Multifinance. Riset Manajemen Dan Akuntansi, ISSN Online: 2338-6576, 1(2), 22-28.

Paputungan, F. R. (2013). Motivasi, Jenjang Karir Dan Disiplin Kerja Pengaruhnya Terhadap Kinerja Karyawan Pada PT. Bank Sulut Cabang Calaca. Jurnal EMBA, ISSN: 2303-1174, 1(4), 679-688.

Permansari, R. (2013). Pengaruh Motivasi dan Lingkungan Kerja Terhadap Kinerja PT. Augrah Raharjo Semarang. Management Analysis Journal, ISSN: 2252-6552, 2(2), 1-9. Retrieved from http://journal.unnes.ac.id/sju/index.php/m aj

Pioh, N. L., \& Tawas, H. N. (2016). Pengaruh Kompensasi Dan Lingkungan Kerja Terhadap Kepuasan Kerja Dan Kinerja Pegawai (Studi Pada PNS Di Kantor Kecamatan Sonder Kabupaten Minahasa). Jurnal Emba ISSN: 2303$1174,4(2), 838-848$.

Poniasih, N. L. G., \& Dewi, A. A. S. K. (2015). Pengaruh Motivasi Kerja, Komunikasi Dan Stres Kerja Terhadap Kepuasan Kerja Karyawan. E-Jurnal Manajemen Unud, ISSN: 2302-8912, 4(6), 1560-1573.

Potu, A. (2013). Kepemimpinan, Motivasi, dan Lingkungan Kerja Pengaruhnva Terhadap Kinerja Karyawan P 33 Kanwil Ditjen Kekayaan Negara Suluttenggo dan Maluku Utara di Manado. Jurnal EMBA ISSN 2303-1174, 1(4), 1208-1218.

Pramadita, A. G. O., \& Surya, I. B. K. S. (2015). Pengaruh Motivasi, Disiplin Kerja dan Lingkungan Kerja Terhadap Kinerja Karyawan Pada PT PLN (Persero) Distribusi di Denpasar Bali. EJurnal Manajemen Unud, ISSN: 23028912, 4(8), 2301-2317.

Priadana, S., \& Ruswandi, I. (2013). Pengaruh Kemampuan Kerja Dan Motivasi Terhadap Kepuasan Kerja Serta Implikasinya Pada Kinerja Pegawai Dinas Pertambangan dan Energi Provinsi Jawa Barat. Jurnal Ekonomi, Bisnis o Entrepreneurship, ISSN 2443-0633, 7, 32 52-63.

Respatiningsih, I., \& Sudirjo, F. (2015). 
Pengaruh Komitmen Organisasi, Motivasi, Kapabilitas Dan Kepuasan Kerja Terhadap Kinerja Pegawai (Studi Empirik Pada Inspektorat Kabupaten Pemalang). Jurnal Ilmiah UNTAG Semarang, ISSN: 2302-2752, 4(3), 5668.

Rizal, M., Syafiie Idrus, M., \& Mintarti, R. (2014). Effect of Compensation on Motivation, Organizational Commitment and Employee Performance (Studies at Local Revenue Management in Kendari City). International Journal of Business and Management Invention, ISSN: 2319801X, E-ISSN: 2319-8028, 3(2), 64-79.

Rudie Yobie, V. P. . L., Bernhard, T., \& Lengkong. (2015). Pengaruh Motivasi Dan Kepuasan Kerja Terhadap Kinerja Karyawan Dimoderasi Oleh Masa Kerja Pada PT . Deho Canning Company Bitung. Jurnal EMBA, ISSN: 2303-1174, 3(1), 717-726.

Rumengan, J. (2013). Metodologi Penelitian. (Kesatu). Bandung: Citapustaka Media Perintis.

Runtunuwu, H. J., Lapian, J., \& Dotulong, L. (2015). Pengaruh Disiplin Kerja, Penempatan dan Lingkungan Kerja Terhadap Kinerja Pegawai Pada Badan Pelayanan Perizinan Terpadu Kota Manado. Jurnal EMBA, ISSN: 23031174, 3(3), 81-89.

Sari, R., Muis, M., \& Hamid, N. (2012). Pengaruh Kepemimpinan, Motivasi, dan Stres Kerja Terhadap Kinerja Karyawan Pada Bank Syariah Mandiri Kantor Cabang Makassar. Jurnal Analisis, ISSN: 2303-1001, 1(1), 87-93.

Simoes, S. C. R. S., Riana, G., \& Subudi, M. (2017). Pengaruh Motivasi Kerja Dan Disiplin Diri Terhadap Kepuasan Dan Kinerja Karyawan Kantor Kabupaten Ainaro Timor Leste. E-Jurnal Ekonomi Dan Bisnis Universitas Udayana, ISSN: 2337-3067, 10(6), 3463-3476.

Soleha, L. K., Komara, A. T., \& Sudia, Y. (2012). Pengaruh Kepemimpinan, Disiplin Kerja, Dan Komunikasi Terhadap Kinerja Pegawai Sekretariat Komisi Penyiaran Indonesia Daerah Provinsi Jawa Barat. Jurnal Ekonomi, Bisnis \& Entrepreneurship, ISSN: $2443-$ 0633, 6(1), 39-50.

Suparno, \& Sudarwati. (2014). Pengaruh motivasi, disiplin kerja dan kompetensi terhadap kinerja pegawai dinas pendidikan kabupaten sragen. Jurnal Paradigma, ISSN: 1693-0827, 12(1), 1225.

Supriyadi, M. F., Priadana, S., \& Setia, B. I. (2017). Kompensasi Dan Disiplin Kerja Terhadap Kepuasan Kerja Karyawan Di Restoran Kampoeng Daun. E-Jurnal Riset Bisnis Dan Manajemen (JRBM), ISSN: 2580-9539, 10(2), 24-33.

Susanti, S., \& Widayat. (2016). Pengaruh Karakteristik Individu, Budaya Organisasi, Dan Komitmen Organisasi Terhadap Kinerja Karyawan Dengan Motivasi Sebagai Variabel Moderasi Akuntabilitas Pengelolaan. E-Jurnal Ekonomika-Bisnis, ISSN: 2442-8604, 7(2), 153-160.

Wahyudi, N. K. S., \& Sudibya, I. G. A. (2016). Pengaruh Kepuasan Kerja dan Komitmen Organisasional Pada Kinerja Karyawan di Natya Hotel Kuta Bali. E-Jurnal Manajemen Unud, ISSN: 2302-8912, 5(2), 870-897. 
